Максименко Ю. А., канд. техн. наук

(0000-0002-1227-2009)

Маміч В. В, канд. техн. наук, доцент

(0000-0001-5574-0901)

Шаріпова I. В.

(0000-0003-0521-1299)

Скачков В. В., д-р техн. наук, професор

(0000-0003-2432-4176)

Військова академія, Одеса

\title{
Комп'ютерне моделювання в органах управління розвідки для аналізу та обробки даних
}

Резюме. Для поліпшення роботи з інформацією, аналізу і обробки іï, обгрунтована необхідність впровадження технологій комп'ютерного візуального моделювання в органах управління розвідки. Надані пропозиції щодо розроблення цих програм.

Ключові слова: органи управління розвідки; комп’ютерне моделювання; розвідувальна інформація; аналіз обстановки; обробка даних.

Постановка проблеми. До органів управління розвідки 3 різних джерел надходить значна кількість розвідувальної інформації, 3 якою потрібно ознайомитись, розподілити за категоріями, обробити, узагальнити, провести аналіз i доповісти вищому керівництву. Більшість цієї інформації спрямовується до спеціалізованих комп'ютерних пристроїв для подальшого іiі оброблення i аналізу. Під час цієї роботи значні витрати часу йдуть на аналіз даних про противника для подальшого прийняття рішення.

На сьогодні необхідне використання відповідних технологій в органах управління розвідки для швидкого аналізу противника, обробки даних та успішного i якісного прийняття рішення.

Аналіз останніх досліджень i публікацій. На сьогодні вже створений i функціонує центральний елемент системи імітаційного моделювання 3С України Центр імітаційного моделювання кафедри інформатизації штабів Національної академії оборони України, де встановлена американська система JCATS.

Програма являє собою імітатор конфліктних ситуацій на землі, у повітрі й на морі, що можуть розв'язуватися на рівні як окремого солдата, так i корпусу швидкого реагування чисельністю до 5 тис. осіб [1].

Подальший розвиток передбачає створення подібних центрів у всіх видових інститутах та об'єднання їх у єдину мережу моделювання UASIMNET (Мережа імітаційного моделювання ЗСУ).

На теперішній час в органах управління розвідкою основна складність прогнозування змін об'єкта реагування полягає у переробленні великої кількості наявних відомостей; а якщо про нього мало що відомо, то основна складність - у нестачі відомостей. Якщо об’ єкт реагування не ізольований ззовні, виникає необхідність прогнозувати не тільки зміни у самому об'єкті, але й можливі впливи, які обумовлюють динаміку таких змін. За такими обставинами використовується метод імітаційного моделювання динаміки розвитку об'єкта, який полягає у прогнозуванні або реконструюванні його сутностей [2].

Використання методу імітаційного моделювання в органах управління розвідки потребує додаткових досліджень. Моделі, що розробляються мають відповідати цілям i конкретним завданням розвідки, а Мережа імітаційного моделювання 3С України потребує відповідного спеціального програмного забезпечення.

Мета статті полягає в обгрунтуванні доцільності впровадження в органи управління розвідкою системи імітаційного моделювання для зменшення часу на обробку необхідних даних, якісного аналізу обстановки та представлення інформації вищому штабу.

Виклад основного матеріалу. В основу оцінювання інформаційних можливостей органу управління розвідки можна покласти систему розвідки (рис. 1).

Для оцінювання інформаційних можливостей розглянемо підсистему інформаційно-аналітичного забезпечення (IA3), як складову системи розвідки.

Підсистема IA3 складається $з$ елементів, тобто органів розвідки, які безпосередньо задіяні у процесі інформаційної діяльності послідовної сукупності операцій збирання, реєстрації, систематизації, аналізу, 
передавання, накопичення, зберігання та видачі інформації для прийняття обгрунтованих рішень згідно 3 обстановкою [2].

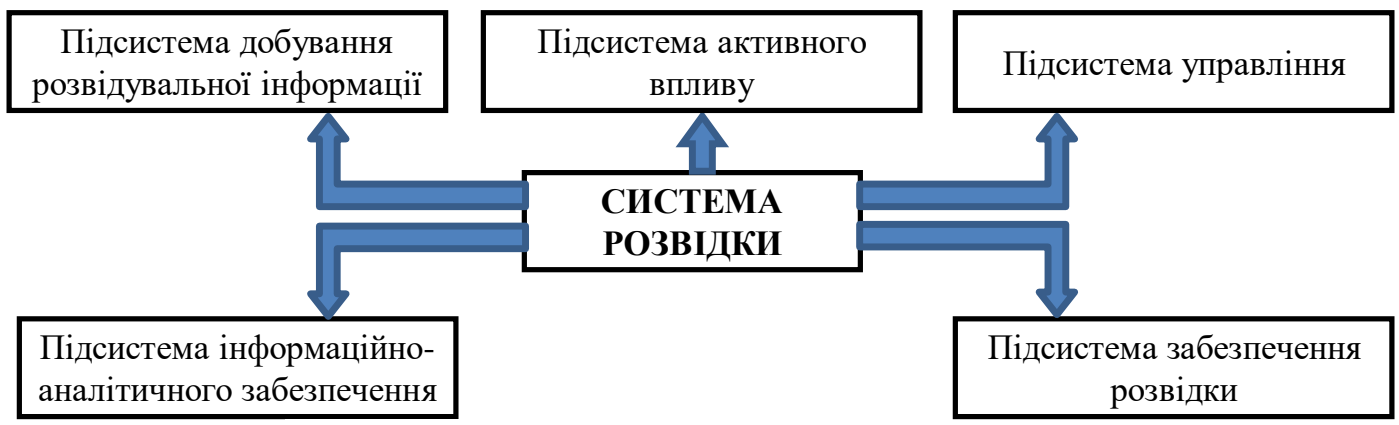

Рис. 1. Функціональна модель системи розвідки

Вибуховий розвиток інформаційних технологій в останні десятиліття призвів до того, що сучасне управління в органах розвідки майже неможливо уявити без застосування комп'ютерної техніки. Проте техніка без спеціального програмного забезпечення для органів розвідки не здатна задовольнити постійно зростаючі потреби щодо обробки інформації та вчасного представлення вищому штабу необхідних даних [3, 4].

Для поліпшення оперативності та виконання завдань підсистемою інформаційно-аналітичного забезпечення можливо застосувати комп'ютерне моделювання, але зазвичай для цього не вистачає ефективних технологій і кадрів [2].

Якщо об'єкт прогнозування добре відомий, то основна складність прогнозування полягає в переробленні великої кількості наявних відомостей; а якщо про нього мало що відомо, то основна складність - у нестачі відомостей. Якщо об'єкт прогнозування не ізольований, а відчуває істотний вплив ззовні, виникає необхідність прогнозувати не тільки процеси у самому об'єкті, але й впливи, здійснювані на об'єкт.

Нині за допомогою комп'ютерних технологій можливо спостерігати i експериментувати за явищами i процесами, що за інших умов було б неможливо.

Отже, комп'ютерне моделювання - це створення об'єкта або явища, з використанням комп'ютерної техніки та математичних, фізичних або логічних систем. Термін "моделювання" в сучасному словнику іншомовних слів визначається як метод дослідження явищ і процесів, що грунтуються на заміні конкретного об'єкта досліджень іншим, подібними до нього - моделлю [5].

Тобто $є$ можливість скористатися технологією візуального моделювання для розвитку інтегрованого середовища. За допомогою системи та методології комп'ютерного моделювання можна розробити віртуальні моделі реального часу районів проведення розвідки. Ці моделі, 3 точністю конструюються шляхом поєднання фотографій, отриманих за допомогою аерофотознімання, зі стереометричними “об'єктами” для реалістичного тривимірного моделювання.

Як зазначає Н. Данешхо (Naqib Daneshjo), існують комп'ютерні моделі двох типів [6]. Периий тип - комп'ютерні моделі, за допомоги яких можна аналізувати об'єкти або системи, перевіряти, спостерігати та уточнювати їх характеристики. Другий тип комп'ютерні моделі (допоміжні), які заздалегідь розроблені (наприклад, модель ділянки територіiі). Такий сервіс підтримується комп'ютерними геотехнологіями. Таким чином йдеться про методи автоматизації проєктування, що потребує спеціального програмного забезпечення.

Нині існує значна кількість комп'ютерних моделей природних процесів та явищ, що дає змогу здійснювати процес аналізу об'єктів простішим, пізнавальним, цікавішим та грунтовним.

Експериментування 3 моделями дає змогу здійснювати глибокий аналіз і визначати характеристики об'єкта, шукати альтернативи або варіанти розв'язання сформульованих завдань [6].

Візуалізація своїх підрозділів, підрозділів противника i ландшафтного оформлення дає змогу органам управління розвідки відчути ефект присутності у спроєктованому просторі. Це дає змогу об'єктивно оцінити обстановку i прийняти правильне рішення.

Задача підтримки інформаційної моделі в необхідному стані полягає в тому, щоб виконувалися операції збереження i 
модифікації інформаційної моделі відповідно до виникаючих змін у складі об'єктів розвідки, зв'язках між ними і їхнім станом. Під об'єктами розвідки розуміємо сили i засоби противника. Системи військових об'єктів - це комплекси взаємопов'язаних підсистем та елементів угрупування, сил, засобів противника, інфраструктури, які несуть загрозу нашим військам i мають важливе значення.

Задача обробки розвідувальних даних у загальному випадку виглядає так: інформація про об'єкти противника надходить 3 джерел інформації (в загальному випадку різнобічних); необхідно визначити їх правдоподібність (задається ймовірністю) залежно від джерела надходження інформації.

Тобто підтверджена інформація про об'єкти, що надходить від органів розвідки, у змодельованому вигляді наноситься 3 урахуванням місцевості. Ймовірність правдивості джерела інформації задає підсистема інформаційно-аналітичного забезпечення.

Відмінною рисою всіх сухопутних боїв $\epsilon$ те, що будь-якій такий бій відбувається на деякій місцевості, яка істотно впливає на його перебіг. У стохастичній моделі інформація про характеристики місцевості не випадкова i $\epsilon$ частиною вихідної інформації для моделювання перебігу бою.

Отримати постійну інформацію про будь-яку реальну місцевість неважко, зокрема вона може бути безпосередньо взята 3 карти. Однак висновки, отримані на моделі 3 використанням такого підходу, можна розповсюдити на досить вузький клас різних типів місцевості.

Як правило, під час моделювання боїв підрозділів сухопутних військ вважають, що кожний елемент у процесі бою веде спостереження за елементами противника, які $\epsilon$ цілями для елементів, що ведуть спостереження. Усі цілі залежно від відстані, різниці висот, рельєфу і рослинності умовно поділяються на дві групи: невидимі та видимі. Цілі першої групи виявити неможливо, цілі другої групи рано чи пізно виявляються. Чим більше введено в програму моделювання підтверджених об'єктів, тим більша ймовірність виявлення всіх підрозділів противника [7].

Конкретний вид функції ймовірності виявлення може бути самим різним - він залежить від типу модельованого реального бойового процесу.
У моделі шукається поточна інформація по виявлених цілях, до того ж визначаються ймовірності знаходження підрозділів поруч.

Розглянемо пропозиції стосовно того, що потрібно враховувати під час розроблення моделей для органів управління розвідки.

Необхідно розробити програми 3 технологією комп'ютерного візуального моделювання для органів управління розвідкою, де 3 урахуванням місцевості та складу підрозділів противника буде наноситись інформація про об'єкти противника, які навіть не підтвердженні. Тобто об'єкти, які підтвердженні наносяться одним кольором, які ні - іншим. За такого виду імітаційного моделювання необхідно представити моделі у форматах 2D та 3Dзображення з програмою, що має можливість розставляти підрозділи противника 3 урахуванням місцевості, штату, відстаней між підрозділами та 3 шляхами можливого просування або підходів. За таких умов необхідно проєктувати та впроваджувати в практику системне комп'ютерне моделювання, де задаються в умовах необхідні показники.

У процесі такого моделювання наглядно видно де необхідно проводити розвідку, наприклад застосовувати безпілотні літальні апаратів (БПЛА), або відправляти розвідувальну групу.

Інтеграція технологій в органах управління розвідки має вирішальне значення для успішного і якісного прийняття рішення. Використання інформаційно-комунікаційних технологій приведуть до значного поліпшення роботи інформаційно-аналітичних відділів. Можливо інтегрувати системи комп'ютерного моделювання в процес для: забезпечення більш глибокого розуміння інформації та іiі аналізу; реалізації складних ідей і побудови гіпотез; аналізу дій противника; пошуку рішення для виконання бойових завдань [8].

Інформаційно-аналітична робота потребує від офіцера-розвідника обробки великої кількості даних та інформації, що потребує високого ступеня абстрактного мислення. Моделювання операцій (бойових дій) може стати цікавим, зрозумілим i швидким прийняттям вірних рішень.

Швидкість впровадження програми багато в чому залежить від темпів оцифровки військової техніки і рельєфу місцевості. При цьому головна проблема в оцифруванні об'єктів противника - їx віртуальні моделі потрібні системі, щоб достовірно прорахувати поведінку 
систем озброєння і зону ураження у разі їх застосування.

Автоматизація прийняття рішень на порядок підвищує час реакції. Отже нині такі системи необхідні в органах управління розвідкою.

Водночас, зарубіжні вчені застерігають, що для отримання максимального ефекту від використання системного моделювання вони мають відповідати цілям і завданням, і бази даних мають постійно підтримувати й оновлюватись до вимог часу.

Висновки. Для оцінювання обстановки, проведення аналізу інформації, підтримки прийняття рішень і підвищення ефективності органів управління розвідки необхідно проєктувати та впроваджувати у практику системне комп'ютерне моделювання.

Під час впровадження такого варіанта IT необхідно враховувати місцевість, склад підрозділів противника, об'єкти противника навіть які не підтвердженні. Тобто об'єкти, які підтвердженні наносяться одним кольором, які ні - іншим. До того ж така програма має автоматично розставляти підрозділи противника з урахуванням місцевості, штату, відстаней між підрозділами та шляхами можливого просування або підходів.

Напрями подальших досліджень Завдання впровадження в практику системного комп'ютерного моделювання 3 урахуванням означених вище складових зводиться до задачі розроблення інформаційної технології, що потребує додаткових досліджень.

\section{СПИСОК ВИКОРИСТАНОЇ ЛІТЕРАТУРИ}

1. Horrocks I., Sattler U., Tobies S. Practical Reasoning for Very Expressive Description Logics. Logic. Journal of the IGPL (Interest Group in Pure Logic). 2000. No 8 (3). pp. 239-263.

2. Аналітична розвідка як компонент розвідувальноінформаційної діяльності / Л. Заболотний, В. Небога, Г. Нестерук та ін. Київ : НУОУ імені Івана Черняховського, 2017. 262 с.

3. Інформаційні технології інформаційноаналітичного забезпечення органів управління військами (силами) : підручник / С. Микусь, В. Солонніков, В. Крайнов, Ю. Даник та ін. Київ : НУОУ імені Івана Черняховського, 2019. 352 с.

4. Вернер І., Козаков Ю., Рябцев В. Застосування сучасних інформаційних технологій в роботі органів управління. Київ : НУОУ імені Івана Черняховського, 2006. 368 с.

5. Семотюк О. П. Сучасний словник іншомовних слів. Харків : Веста : Ранок, 2008. 374 с.

6. Daneshjo N. Computer Modeling and Simulation. International Conference on Optimization of the Robots and Manipulators. University Politehnica of Buchares (OPTIROB 2011), May 26.

7. Копаєв О. В. Алгоритм як модель алгоритмічного процесу. URL: http://www.ii.npu.edu.ua/files/ Zbirnik_KOSN/6/21.pdf.

8. Margaret A. Honey and Margaret L. Hilton. Editors; Learning Science Through Computer Games and Simulations. 2011. 174 p.

Стаття надійшла до редакційної колегії 09.11.2020

\section{Computer simulation in intelligence agencies for data analysis and processing}

\section{Annotation}

At present time, intelligence agencies receive a large amount of information about the enemy, which must be processed, summarized, analyzed and reported to decision makers. Most of this information is entered into computer programs for further processing and analysis. During this process a large amount of time is spent on the analysis of data about the enemy for further decision-making.

Currently the simulation method is used to predict or reconstruct changes in certain entities of the programs of their computer models. It is a formal method that uses manipulated symbols, but does not take into account the possible manifestations of the intellectual activity of certain subjects that affect the entities they study.

But the formal method of modeling does not allow analyzing the enemy actions. This requires an effective way to imagine and analyze the "physical consequences" of the project before setting objectives. To improve the information analysis and processing of it, it is necessary to consider the use of information technologies with the system modeling that takes into account some indicators and provide the possibility for further forecasting. The integration of technology in intelligence agencies for rapid analysis, data processing and successful decisionmaking is needed today.

It is proposed for intelligence agencies to develop programs with the possibilities of visual computer modeling where the location and composition of enemy units tooked into account. Information about the enemy are caused in different colors, having an information about its approximate composition, the software arranges enemy units considering with the nature of the terrain, number and distances between units with predicted ways of possible advancement or approaches.

To provide a deeper understanding and analysis of the information, recommendations are provided for the use of computer modeling in intelligence agencies. Processing.

Keywords: intelligence agencies; computer simulation; intelligence information; situation analysis; Data 